\title{
The right coronary artery originating from the left anterior descending artery: A variant of single coronary artery anomaly
}

\section{Sol ön inen koroner arterden kaynaklanan sağ koroner arter: Tek koroner arter anomalisinin farklı} bir tipi

\section{Yakup Alsancak ${ }^{1}$, Sina Ali ${ }^{2}$}

\begin{abstract}
Although coronary artery anomalies have been accepted as benign conditions, clinical presentations have a large spectrum including chest pain, dyspnea, palpitations, malign arrhythmias, myocardial infarction, syncope and sudden death. An atypical anomalous form of single coronary artery in which the right coronary artery originates from the left anterior descending (LAD) coronary artery is an extremely rare situaiton.

In this report, we presented a case of 63 years old woman who was taken to the coronary angiography due to recurrent chest pain and acute coronary syndrome. Coronary angiography revealed an atypical form of single coronary artery anomaly that the right coronary artery originates from LAD coronary artery. The treatment strategy was discussed with heart team and patient. Percutaneous coronary intervention (PCI) was performed because of her recurrent chest pain and isolated LAD lesion and preference of the patient.

In conclusion, this case is important for demonstrating the feasibility of PCI in patients with single coronary artery anomaly.
\end{abstract}

Keywords: Anomaly, percutaneous intervention, single coronary artery

\section{Öz}

Benign bir durum olarak kabul edilmelerine rağmen, koroner arter anomalilerinin klinik görünümü göğüs ağrısı, nefes darlığı, çarpıntı, malign aritmiler, miyokard enfarktüsü, senkop ve ani ölüm gibi geniş bir spektruma sahiptir. Sağ koroner arterin sol ön inen koroner arterden köken aldığı tek koroner arterin atipik formu son derece nadir bir koroner anomalidir.

$\mathrm{Bu}$ yazıda, tekrarlayan göğüs ağrısı ve akut koroner sendrom nedeniyle koroner anjiyografiye alınan 63 yaşında bir kadın olgu sunuldu. Koroner anjiyografide, sağ koroner arterin sol ön inen koroner arterden köken aldığı atipik bir tek koroner arter anomalisi saptandı. Tedavi stratejisi kalp takımı ve hasta ile tartışıldı. Tekrarlayan gögüs ağrısı, izole sol ön inen koroner arter lezyonu ve hastanın tercihi nedeniyle perkütan koroner girişim (PKG) yapıldı.

Sonuç olarak, bu olgu, tek koroner arter anomalisi olan hastalarda PKG'in uygulanabilirliğini göstermesi bakımından önemlidir.

Anahtar kelimeler: Anomali, perkütan girișim, tek koroner arter
${ }^{1}$ Necmettin Erbakan University, Meram Faculty of Medicine, Department of Cardiology, Meram, Konya, Türkiye.

${ }^{2}$ Etimed Hospital, Department of Cardiology, Etimesgut, Ankara, Türkiye.

Informed Consent: The written consent was received from the patient who was presented in this study.

Hasta Onamı: Çalışmada sunulan hastadan yazılı onam alınmıștır.

Conflict of Interest: No conflict of interest was declared by the authors.

Çıkar Çatışması: Yazarlar çıkar çatışması bildirmemişlerdir.

Financial Disclosure: The authors declared that this case has received no financial support. Finansal Destek: Yazarlar bu olgu için finansal destek almadıklarını beyan etmişlerdir.

Gelis Tarihi / Received: 17.09.2018

Kabul Tarihi / Accepted: 28.12.2018

Yayın Tarihi / Published: 15.03.2019

Sorumlu yazar / Corresponding author Yakup Alsancak

Adres/Address: Necmettin Erbakan University, Meram Faculty of Medicine, Department of Cardiology, Meram, Konya, Türkiye. Postal code: 42090.

e-mail: dryakupalsancak@gmail.com Tel/Phone: +900332 2236500

Copyright $\mathbb{C}$ ACEM 


\section{Introduction}

Most of the coronary artery anomalies (CAA) are detected incidentally during coronary angiography and are usually asymptomatic. Altough they have been accepted as a benign condition, clinical presentation of CAA has a large spectrum including chest pain, dyspnea, palpitations, malign arrhythmias, myocardial infarction, syncope and sudden death [1, 2]. An isolated single CAA is defined as a solitary coronary artery arising from the sinus valsalva, giving rise to the major coronary branches such the left anterior descending coronary artery (LAD), the circumflex artery and the right coronary artery (RCA). In other words, both the left main coronary artery and the RCA arise from a single aortic sinus. The prevelance of single CAA have been reported as a range of $0.031 \%$ to $0.066 \%[3,4]$. The atypical form of single coronary artery that RCA originates from LAD is an extremely rare coronary anomaly [1].

Herein, we present a case of atypical form of single CAA that presented with acute coronary syndrome and successfully managed with percutaneous coronary intervention (PCI).

\section{Case report}

A 61-year-old female patient was admitted to our emergency department with chest pain that had lasted one hour. Except from diabetes mellitus and chronic renal failure, there was no reported history of cardiac risk factor. On admission, her electrocardiography revealed normal sinus rythm with $95 / \mathrm{min}$ heart rate and ST depression on anterior derivations without ST elevations. The echocardiographical examination revealed left ventricular hypertrophy with normal systolic function. After that day, she was transferred to catheter laboratuary due to recurrent chest pain and elevated troponin levels. Her coronary angiography revealed an anomalous RCA originating from the middle portion of LAD which had severe thrombotic stenosis at the above of RCA ostium (Figure 1 A-D). This patient was accepted as a two-vessel disease because of both LAD and RCA being affected by thrombotic stenosis. We discussed the option of surgical treatment or PCI with the patient. Because of her recurrent chest pain and isolated LAD lesion and preference of the patient, we decided to perform PCI. A floppy guidewire was advanced into the RCA and a second wire was reach down to the LAD. 3.0x18 mm drug eluting stent was directly implanted with a high pressure, and postdilatation was performed with a $3.5 \times 15$ mm non-compliant balloon. Coronary angiography demonstrated the successful outcome after stent implantation without any stenosis or obstruction of RCA ostium. (Figure 2 A-D). Computed tomographic angiography (CTA) could not been performed to show the course of the coronary arteries because of the patient's chronic renal failure. Patient was discharged after two days without any complication.

Written consent was taken from the patient.

\section{Discussion}

The incidence of CAA is $1.3 \%$ and RCA is known as the most commonly affected coronary artery [5]. It is well known that many of anomalous origin of the RCA are asymptomatic, but Taylor et al. [6] has demonstrated a $25 \%$ rate of sudden death with this situation. Moreover, it has been reported that congenital anomalies such as coronary arteriovenous fistula, transposition of the great vessels or bicuspid aortic valve may be related with single coronary anomaly [7]. Single CAA may also be detected as a cause of sudden cardiac death with a range of $4 \%$ to $15 \%$ in younger populations [8]. Single CAA may have benign or malignant prognosis due to its location, but generally accepted as a hemodynamically benign form of CAA's. Single CAA arising from the left sinus valsalva has a more benign prognosis than arising from the right sinus valsalva. And, that arising from the left sinus valsalva may be associated with sudden cardiac death after vigorous exertion before age of 20 [9]. Although the majority of CAAs were detected during conventional coronary angiography, it is not always a sufficient method to assess the prognosis of the disease. CTA may have a more beneficial role to identify the course of the coronary arteries and their associations with structural tissues [9]. Ghadri JR et al. [10] have demonstrated that the confirming of CAA's is higher with CTA than standard coronary angiography. And they also supported that standard coronary angiography is not enough technique to identify the CAA's.

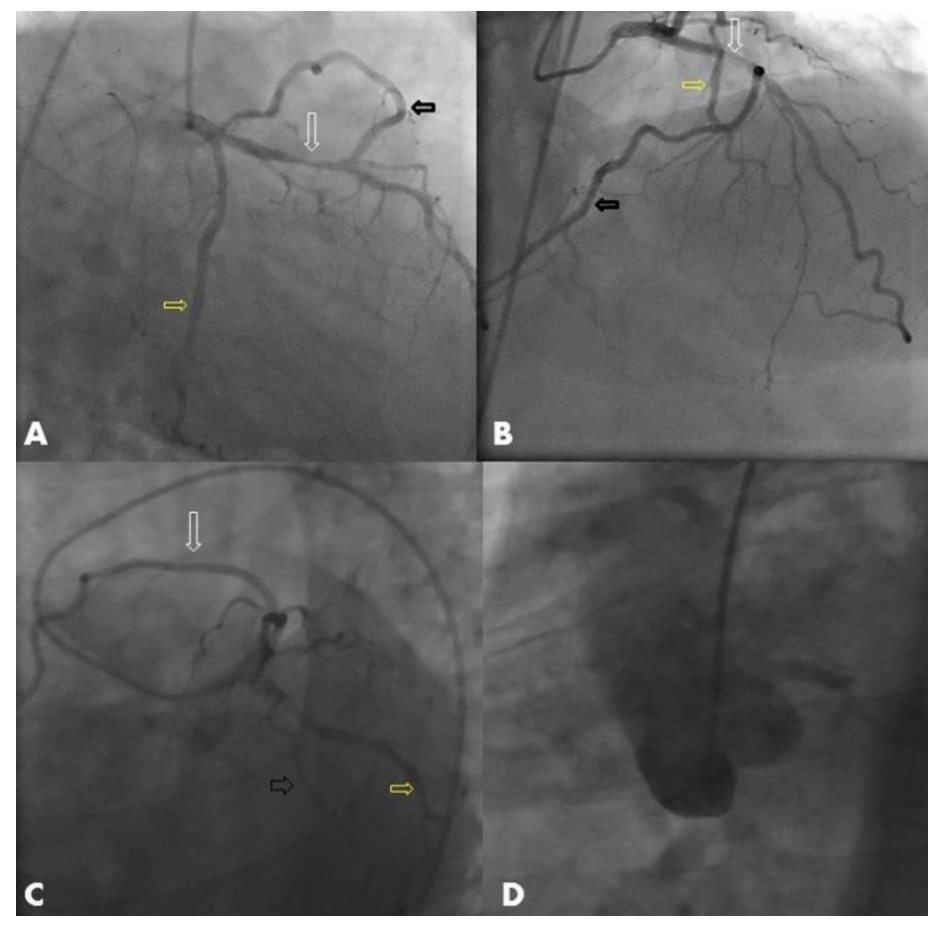

Figure 1. The left anterior descending coronary artery with severe thrombotic stenosis (white arrows), the circumflex coronary artery (yellow arrows) and anomalous right coronary artery from mid portion of the left anterior descending coronary artery (black arrows) (A-C) Aortography demonstrated the left main coronary artery without the right coronary ostium in the right sinus valsalva (D).

The run of the coronary arteries is the one of the main determinants for the patient's prognosis. It may cause myocardial ischemia or sudden cardiac death during exercise, if it is located between the aorta and the surrounding tissues such as the pulmonary trunk [11]. Moreover, acute coronary syndromes, in these patients, have an increased risk for cardiovascular death compared with the patients who have normal coronary anatomy because of the excessive ischemic burden. Even in patients with single-vessel disease that need revascularization, treatment should be well considered. Medical, surgical or PCI may be a choice for treatment and such methods should be well discussed with patients.

Several case reports were published about percutaneous revascularization to single CAA $[2,12]$. Percutaneous coronary interventions may be lethal as a result of complications during procedure due to wide ischemic area and complex coronary anatomy. Comparing with normal population, PCI in patients with CAA has considerable technical difficulties [13]. Mishra TK and colleagues [12] have been well summarized the risks involved in the process during percutaneous interventions. At 
first, they mentioned that procedure has a similar risk with intervention of unprotected the left main coronary artery disease due to the large size of the threatened myocardial area. Any coronary dissection that occurs during catheter manipulation or percutaneous interventions (guidewire induced or balloon dilatation or edge dissection after stent implantation) may result in death. In addition, prolonged dilation of coronary balloons may cause of development of malignant arrhythmias. Stent thrombosis can lead to fatal consequences for patients in short and long term follow up [12]. Finally, drug eluting stents must be chosen because of that the use of drug eluting stents versus bare metal stents are associated with significant reductions in major adverse cardiovascular events, all-cause mortality, myocardial infarction, target-lesion revascularization, and target-vessel revascularization in patients with chronic kidney disease [14].

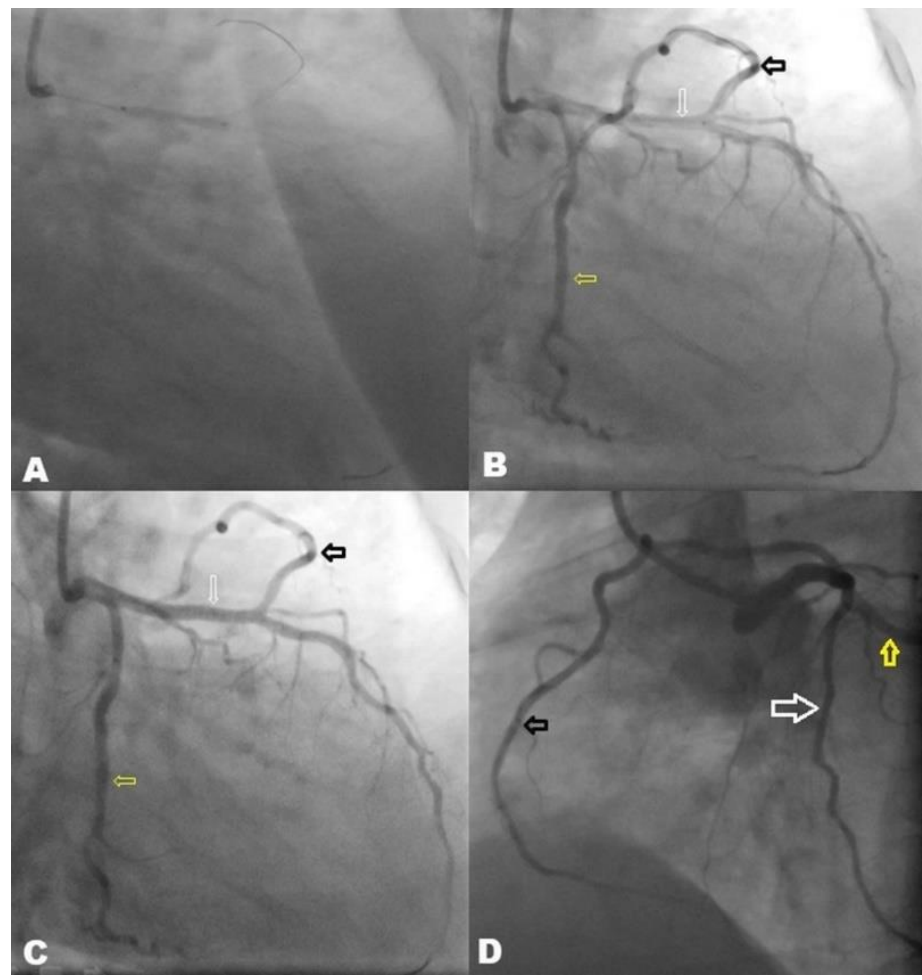

Figure 2. Stages of percutaneous coronary intervention (black arrows: the right coronary artery, white arrows: the left anterior descending coronary artery, yellow arrows: the circumflex coronary artery (A-C). The course of the right coronary artery in right anterior oblique view (D).

In this case, we preferred PCI due to comorbid conditions of the patient. Because of the excessive ischemic burden, PCI might be performed with mechanical assisted device with support of cardiovascular surgery. This case is important for demonstrating the feasibility of PCI in patients with single coronary artery anomaly.

\section{References}

1. Yurtdas M, Gulen O. Anomalous origin of the right coronary artery from the left anterior descending artery: review of the literature. Cardiol J. 2012;19:122-9.

2. Alsancak Y, Sezenöz B, Duran M, Unlu S, Turkoglu S, Yalcın R. Acute Anterior Myocardial Infarction Accompanied by Acute Inferior Myocardial Infarction: A Very Rare Coronary Artery Anomaly. Case Rep Cardiol. 2015;2015:347126-3.

3. Desmet W, Vanhaecke J, Vrolix M, Van de Werf F, Piessens J, Willems $\mathrm{J}$, et al. Isolated single coronary artery: a review of 50,000 consecutive coronary angiographies. Eur Heart J. 1992;13:1637-40.

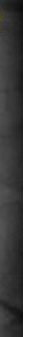

4. Turkmen S, Yolcu M, Sertcelik A, Ipek E, Dokumaci B, Batyraliev T. Single coronary artery incidence in 215,140 patients undergoing coronary angiography. Folia Morphol (Warsz). 2014;73:469-74.

5. Yamanaka O, Hobbs RE. Coronary artery anomalies in 126,595 patients undergoing coronary arteriography. Cathet Cardiovasc Diagn. 1990;21:28-40.

6. Taylor AJ, Rogan KM, Virmani R. Sudden cardiac death associated with isolated congenital coronary artery anomalies. J Am Coll Cardiol. 1992;20:640-7.

7. Ogden JA, Goodyer AV. Patterns of distribution of the single coronary artery. Yale J Biol Med. 1970;43:11-21.

8. Alexander RW, Griggith GC. Anomalies of the coronary arteries and their clinical significance. Circulation. 1956;14:800-5.

9. Villa AD, Sammut E, Nair A, Rajani R, Bonamini R, Chiribiri A Coronary artery anomalies overview: The normal and the abnormal. World J Radiol. 2016;8:537-55.

10. Ghadri JR, Kazakauskaite E, Braunschweig S, Burger IA, Frank M, Fiechter M, et al. Congenital coronary anomalies detected by coronary computed tomography compared to invasive coronary angiography. BMC Cardiovascular Disorders. 2014;14:1.

11. Wańha W, Roleder T, Kowalówka A, Wojakowski W. Acute coronary syndrome in a patient with an anomaly of the right coronary artery, which originated from the medial part of the left anterior descending artery. Kardiol Pol. 2015;73:375.

12. Mishra TK, Mishra CK, Das B. Percutaneous coronary intervention in a patient with single coronary artery. Indian Heart J. 2014;66:382-5.

13. Lanzieri M, Khabbaz K, Salomon RN, Kimmelstiel C. Pri $\neg$ mary angioplasty of an anomalous left main coronary artery: diagnostic and technical considerations. Catheter Cardiovasc Interv. 2003;58:185-8.

14. Lu R, Tang F, Zhang Y, Zhu X, Zhu S, Wang G, et al. Comparison of Drug-Eluting and Bare Metal Stents in Patients With Chronic Kidney Disease: An Updated Systematic Review and Meta-Analysis. J Am Heart Assoc. 2016;5:e003990.Alergol. 2018;35:225-6.

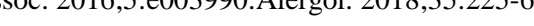

